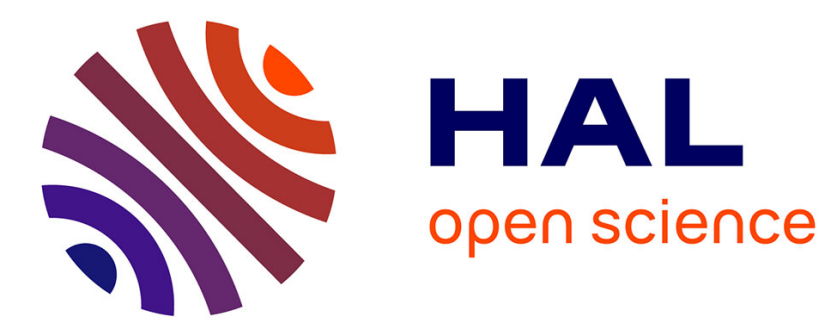

\title{
Some results on environmental and human toxicity involved by greenhouse tomato production in France
}

Thierry Boulard, Richard Brun, F. Hayer, G. Gaillard, François Lecompte

\section{To cite this version:}

Thierry Boulard, Richard Brun, F. Hayer, G. Gaillard, François Lecompte. Some results on environmental and human toxicity involved by greenhouse tomato production in France. International Symposium on Advanced Technologies and Management Towards Sustainable Greenhouse Ecosystems: Greensys2011, Jun 2011, Athènes, Greece. hal-02749788

\section{HAL Id: hal-02749788 \\ https://hal.inrae.fr/hal-02749788}

Submitted on 3 Jun 2020

HAL is a multi-disciplinary open access archive for the deposit and dissemination of scientific research documents, whether they are published or not. The documents may come from teaching and research institutions in France or abroad, or from public or private research centers.
L'archive ouverte pluridisciplinaire HAL, est destinée au dépôt et à la diffusion de documents scientifiques de niveau recherche, publiés ou non, émanant des établissements d'enseignement et de recherche français ou étrangers, des laboratoires publics ou privés. 


\title{
Some Results on Environmental and Human Toxicity Involved by Greenhouse Tomato Production in France
}

\author{
T. Boulard', R. Brun', F. Hayer ${ }^{2}$, G. Gaillard ${ }^{2}$ and F. Lecompte ${ }^{3}$ \\ ${ }^{1}$ INRA-URIH , 400, Sophia Antipolis, France \\ ${ }^{2}$ Agroscope Reckenholz-Tänikon ART, Zürich, Switzerland \\ ${ }^{3}$ INRA-PSH, Domaine Saint Paul, Site Agroparc, Avignon, France
}

Keywords: greenhouse, tomato, LCA, exposure, environmental impact

\begin{abstract}
Environmental acceptability of greenhouse production with respect to intensification is a controversial question. The environmental impact decreases with the use of impacting inputs while it increases with the intensification of the system. Choosing the right equilibrium between the necessary limitation of the inputs on one side and the necessary intensification of the system on the other side is an important question, giving contradictory results, often depending on the considered impact. In this study we focus on human and environmental toxicity and, based on Life Cycle Assessment (LCA) of heated and non heated greenhouse tomato production in France, we have considered all the potential toxicity impacts of this production. As the spatial scale of the toxicological assessment used within LCA does not make allowance for the confined character of greenhouses, where toxic exposure is very local, we have completed this approach by an occupational indicator study, developed for evaluating the exposure of operators and workers to the active substances in plant protection products. Preliminary results of these studies show that considering LCA approach, the toxicological impact of pesticide application appears much lower than the use of heating (for heated production). Examining what happens inside the greenhouse, the occupational indicator study shows that both operators and re-entry workers have a risk index greater than 1 for a large percentage of the active ingredients used, the exposure being much larger for reentry worker's in tunnel than in multispan greenhouse. Scenario study shows that a simple protection policy was sufficient to lower the risk index of a factor 10 .
\end{abstract}

\section{INTRODUCTION}

Greenhouse production uses intensive techniques not used in other agricultural systems: $\mathrm{CO}_{2}$ enrichment, artificial lighting, soilless cultivation and heating, which impacts have rarely been addressed and which have contradictory consequences for the environment: on one side the impact per unit of cropping area is greater but on the other side the impact per unit of product is less.

As life cycle assessment (LCA) considers the whole system and covers most impacts generated by greenhouse production, it can be deployed to realize the balance between these contradictory aspects. It is certainly why one of the first LCA studies applied to agricultural systems was devoted to the study of the environmental impact of greenhouse tomato production for Swiss conditions (Jolliet, 1993). More recently, using LCA the environmental impact of soilless tomato growing was explored in Spain by Antòn et al. (2004) and of greenhouse heating in the Netherlands by Nienhuis (1996) and Pluimers et al. (2000) and in Great Britain by Williams et al. (2006). All found that heating was the main contributor to most impacts, but also that impact per $\mathrm{kg}$ of product depends very much on yield. However they did not establish whether the increase in yield exceeded the increase in energy inputs and one can hardly determine which is the right equilibrium between the necessary limitation of the inputs and the required intensification of the system. In addition, due to the confinement characteristics of greenhouse production, most of these studies assess that LCA is not always the best method for determining the human toxicity of the pesticides used in this specific environment.

Based on these observations we designed this study to quantify on a 
complementary way the toxicological impact of greenhouse tomato production in France at the regional scale and at the greenhouse scale, the exposure of the greenhouse workers to pesticides.

Our study is based on the same France-wide greenhouse tomato production data base which is exploited (i) for determining, using LCA, the toxicity impacts of tomato production on terrestrial and aquatic ecosystems on human health (Boulard et al., 2011) and (ii) for assessing the exposure of the applicators and re-entry workers to the active ingredients (a.i.'s) used for plant protection (Hayers et al., 2011).

\section{MATERIALS AND METHODS}

\section{The Data Base}

The data base concerns the widespread French greenhouse production: tomato cultivation with (i) soilless and heated tomato crops in glass or plastic multispans in the north-west (Brittany and lower Loire Valley) and in the south-east (Mediterranean area and the lower Rhone Valley) France and (ii) in unheated, soil-based tomato production under high polytunnels, also in south-east France. Areas and production per region are given in Table 1 and one can see that the selected regions (lower Rhone valley and Catalogne for the south and lower Loire valley and Brittany for the north) represent $92 \%$ of the whole fresh tomato production.

Comparison between sophisticated and simple production systems allows us to examine the dependence of the environmental impact of the production system on its degree of intensification. Also we consider whether there is a correlation between the environmental impact of tomato production and its geographical situation.

However, as fresh (as opposed to processing) tomatoes are no longer grown in large quantities outdoors in France, field cropping has not been considered in this study.

The main features of the greenhouse tomato cropping systems under investigation in France are given in Table 1. They are based on data on protected tomato cropping collected for this study from 2006-2008. Production inputs were obtained from the management centres of the Chambers of Agriculture of the Brittany and Pays de Loire regions for the north-west and the Provence Côte d'Azur and Languedoc-Roussillon regions for the south-east. For energy consumption, which needs a special focus, the data were taken from an in-depth investigation of energy consumption for greenhouse crops, conducted by two technical institutes (CTIFL, Astredhor) and the French Environment and Energy Management Agency (ADEME) during the years 2005 to 2007 (Vésine et al., 2007). Additional data were provided by various companies in the French horticultural sector (greenhouse construction, climate control, fertigation, etc...).

The different active ingredients (a.i.'s) considered for tomato production in tunnels and greenhouse are given in Tables 2 .

\section{Greenhouse Tomato Production Life Cycle Assessment}

LCA main principles can be found in Jolliet et al. (2005) and its application to greenhouse tomato production in France is exposed in details in Boulard et al. (2011), particularly the specific aspects of LCA for greenhouse and tunnel production. Here the main features of this study are stressed. The selected functional unit is the $\mathrm{kg}$ of fresh tomato. The system boundary is defined at the farm gate and it incorporates (i) the extraction and preparation of the raw materials and energy used for infrastructure and production; (ii) manufacture of structures and equipment; (iii) transport of system inputs i.e. $20 \mathrm{~km}$ for all inputs, except $150 \mathrm{~km}$ for glasshouses in the north-west and plastic houses and tunnels in the south-east and $1200 \mathrm{~km}$ for glasshouses in the south-east and plastic houses in the north-west; (iv) disposal of production waste and structures at the end of the activity; (v) tomato packaging, but not transport.

Inside greenhouses, pesticide transfer is quite different from that in field cropping conditions. For this reason, but also due to the lack of a standard method for calculating pesticide emissions from greenhouses, we estimated the toxicity caused by pesticide 
applications separately from the other toxicological effects. However, the impacts from pesticide production have been considered together with the inputs, separately from its application.

Exposure of Operators and Workers to the Active Substances in Greenhouse Plant Protection Products

Of course LCA of tomato production considers an environmental impact at the regional scale. and the direct exposure of greenhouse workers to pesticides in a very confined environment is not concerned. To account for the exposure of greenhouse workers it is necessary to estimate their potential exposure under different scenarios. Such an approach has already been performed it is the acute derived Pesticide Occupational and Environmental Risk Indicator (POCER) and it is described in a Harmonised environmental Indicators for pesticide Risk (HAIR) project report (Garreyn et al., 2003).

The Acute Risk Indicators (ARI) proposed in the report concern the potential exposure of operators who spray pesticides and the re-entry workers under different scenarios. ARI are equal to the estimation of Potential Exposure (PE) under different scenarios divided by the Acceptable Operator Exposure Level (AOEL) (ARI= PE/AOEL)

Dermal, inhalation and oral exposure during mixing/loading and application are considered for the applicators and inhalation and dermal exposure for the re-entry workers together with personal protective equipment coefficients for gloves, overall and protective mask. Detailed calculations and parameters involved by the method can be found in Hayer et al. (2011). In this study, the ARI was computed for tunnel and glasshouse productions for operators equipped Personal Protection Equipments (PPE) constituted of gloves, body protection and protective masks. For re-entry workers it was computed according to 3 scenarios of Personal Protection Equipments (PPE) and re-entry policy:

policy:
Scenario 1: Operator with PPE, re-entry worker without PPE on the hands and the body and a re-entry time $8 \mathrm{~h}$ after application.

Scenario 2: Operator with PPE, re-entry worker without PPE. Re-entry time dependent from a.i.'s.

Scenario 3: Operator and re-entry worker with PPE (gloves and body protection). Reentry time dependent from a.i.'s.

\section{RESULTS}

\section{LCA Approach}

For detailed results of the LCA of tomato production in France, the readers can refer to Boulard et al. (2011) who present its environmental consequences for 10 impacts. In this paper, we shall only focus on toxicity on human health and ecosystems.

\section{Impacts without Pesticides}

As already stated, the impact of pesticide application was studied separately and was not included in the results. In multi-span greenhouses, ecotoxicity was 4 to 5 times greater than for tunnels because of the heating, which contributed $76-82 \%$ of the impact (Table 3). Emissions of heavy metals, such as chromium and mercury, and aromatic polycyclic hydrocarbons due to heating were the main causes of toxicity.

\section{Specific Impacts of Pesticides}

The comparison of pesticide application impacts with impacts for the rest of the production system (infrastructure, heating etc.) showed that pesticides were of little importance (Fig. 1). The share due to pesticide application was negligible for multi-spans for all toxicity impacts $(\leq 0.36 \%)$. This is because of the huge impact of hydrocarbons emitted during heating and also the reduced use of pesticides due to IPM practices. Air humidity control in heated greenhouses adds $20 \%$ to heating energy consumption and so has a considerable environmental impact. Looking now the share of the different a.i.'s 
used (Fig. 2), one can see that copper sulphate massively used in tunnel again fungal disease's is the major cause of impact for the three considered toxicity impacts. Even though the calculation of pesticide emissions might cause a substantial uncertainty (Boulard et al., 2011), the results indicate that the active ingredients applied in greenhouses have a lower impact than the ones assumed to be used in the tunnel system. More generally, these results are in line with the spread of IPM practices in heated greenhouses and particularly the increasing use of dehumidification against fungi.

\section{POCER Approach}

Figure 3 depicts the internal exposure, AOEL and risk index of operators for the different a.i.'s used in multispan greenhouses and tunnels for tomato production. For multispan greenhouses, one can state that approximately. $50 \%$ of the a.i.'s (8 out of 16) cause a risk index for operators which is approximately of the same order of magnitude than the acceptable exposure level (AOEL) and 3 are greater than the AOEL, and even 2 times greater for the Pyrimethanil. For tunnels, approximately $45 \%$ of the a.i.'s ( 5 out of 11) cause a risk index for operators which is approximately of the same order of magnitude than the acceptable exposure level (AOEL) but 3 are much greater than the AOEL, and even 10 times greater for the Copper-Sulfate and between 20 and 30 times for the Methomyl.

For the different a.i.'s used in multispan greenhouses and tunnels for tomato production, Figure 4 presents the internal exposure, AOEL and risk index of re-entry workers according to the 3 studied re-entry and PPE scenarios. For multispan greenhouses and tunnels one can clearly state that the re-entry scenario (see scenarios 1 and 2 ) has almost no influence on the risk index for the re-entry workers. However, considering now scenario 3 with personal protection equipments on the hands and the body, one can see that even simple PPE's reduce drastically (factor 10) the risk index of re-entry worker's. For greenhouses, the risk index without PPE's is of the same order of magnitude than AOEL for about $30 \%$ ( 5 out 16 ) of the a.i.'s whereas only one a.i. reaches this magnitude with PPE's. For tunnels, the risk index without PPE's is of the same order of magnitude than AOEL for about $55 \%$ (6 out 11) of the a.i.'s and as for operators, it can be much greater ( 3 to 30 times) for three of them (Propamocarbe, Copper-sulfate and Methomyl). With PPE's. the risk index is of the same order of magnitude than AOEL for only $18 \%$ of the a.i.'s ( 2 out of 11 ).

\section{DISCUSSION AND CONCLUSION}

Based on LCA approach, the toxicological impact of pesticide application appears very low with respect to heating. Consequently, plant health management through climate control (heating + ventilation) has a greater impact than through fungicides. A similar estimation could be made for biological control, which also uses additional energy to assist the establishment of the beneficial predators. For tunnels (Fig. Ib), pesticides represent a significant impact only for terrestrial ecotoxicity $(11.15 \%)$. More generally, whatever the type of shelter used, confinement of the pesticides inside the shelters is also responsible for this result because only the toxicological impacts of the pesticides that leave the greenhouse are assessed. For examining what happens inside the greenhouse, the POCER approach is crucial. It clearly shows that both operators and re-entry workers have a risk index greater than 1 for a large percentage of the a.i.'s used, (when operators and the re-entry workers are possibly the same as in many cases, the risk index can be added) the exposure being much larger for re-entry worker's in tunnels than in multispan greenhouses.

Our scenario study shows that the re-entry policy has little influence on the risk index, but that protection policy with gloves and body protections (clothes with sleeves) of the re-entry worker's is sufficient to approximately lower the risk index of a factor 10. However one must keep into mind the limitations of both approaches and particularly for POCER the lack of data concerning the absorption coefficients, the exposure estimations, the AOEL's themselves and the degradation rates on plant 


\section{Literature Cited}

Antón, A., Castells, F., Montero, J.I. and Huijbregts, M. 2004. Comparison of toxicological impacts of integrated and chemical pest management in Mediterranean greenhouses. Chemosphere 54(8):1225-1235.

Boulard, T., Raeppel, C., Brun, R., Lecompte, F., Hayer, F., Carmassi, G. and Gaillard, G., 2011. Environmental impact of greenhouse tomato production in France. Agron. Sust. Dev: (in press)

Garreyn, F., Vagenende, B. and Steurbaut, W. 2003. Harmonized environmental Indicators for pesticides Risk Occupational Indicators: Operator, workers and bystander. Report financed by the EU sixth Framework Programme, Contact number SSPEC-CT-2003-501977.

Hayer, F., Boulard, T., Raeppel, C. and Gaillard, G. 2011. Two pesticides application strategies in Tomato and their risk for workers. Reme rencontres du Végétal, Agrocampus Ouest, Angers. http://rencontres-du-vegetal.inh.fr/communications souserreschauffees.php\#Gaillard.

Jolliet, O. 1993. Bilan écologique de la production de tomates en serre. Revue suisse Vitic. Arboric. Hort. 25(4):261-267.

Nienhuis, J.K. 1996. Utility of the environmental life cycle assessment method in horticulture. Acta Hort. 429:531-538.

Pluimers, J.C., Kroeze, C., Bakker, E.J., Challa, A.H. and Nordijk, L. 2000. Quantifying the environmental impact of production in agriculture and horticulture in The Netherlands: which emissions do we need to consider? Agric. Sys. 66:167-189.

Vésine, E. (coordinator), Grisey, A., Pommier, F., Chantry, A., Plasentin, J. and Chassériaux, G. 2007. Utilisation rationnelle d'énergie dans les serres: situation technico-économique en 2005 et leviers d'action actuels et futurs. Etude réalisée pour le compte de l'ADEME. http://www2.ademe.fr/servlet/getDoc?cid=96\&m=3\&id= $44445 \& \mathrm{pl}=02 \& \mathrm{p} 2=07 \& \mathrm{ref}=17597$

Williams, A.G., Audsley, E. and Sandars, D.L. 2006. Determining the environmental costs and resources use in the production of agricultural and horticultural commodities. Main Report. Defra Research Project ISO205. Bedford: Cranfield University and Defra. http://www.defra.gov.uk 


\section{Tables}

Table 1. Main characteristics of the protected tomato cropping systems in France for the years 2006-2008. 1) Total area and tomato type distributions with respect to greenhouse systems and production zones (north-west refers to Brittany and lower Loire Valley and south-east to Rhone Delta and Mediterranean regions). 2) Heating energy consumptions is derived from a nationwide study of 130 greenhouses (Vésine et al., 2007). 3) Main characteristics of the production systems considered and 4) Yields and market prices (from Agreste, 2008, 2009).

\begin{tabular}{|c|c|c|c|c|c|c|c|}
\hline & & \multicolumn{2}{|c|}{ Glasshouse } & & \multicolumn{2}{|c|}{ Plastichouse } & \multirow{2}{*}{$\begin{array}{l}\text { Tumnel } \\
\text { South-East }\end{array}$} \\
\hline & & North-West & South-East & & North-West & South-East & \\
\hline \multirow[t]{2}{*}{ Total Area } & & \multicolumn{2}{|c|}{64} & \multicolumn{3}{|c|}{6} & 30 \\
\hline & Bulk & 28 & 40 & & 50 & 40 & 100 \\
\hline \multirow[t]{2}{*}{ Tomato type (\% surface) } & On the une & 46 & 50 & & 50 & 50 & 0 \\
\hline & Special types & 26 & 10 & & 0 & 10 & 0 \\
\hline Structure & & $\begin{array}{l}\text { Concrete- } \\
\text { Steet } \\
\text { Aluminium- } \\
\text { Glass }\end{array}$ & $\begin{array}{l}\text { Concrete- } \\
\text { Steet- } \\
\text { Ahuminium. } \\
\text { Glass }\end{array}$ & & $\begin{array}{c}\text { Steel- } \\
\text { Polyethylene }\end{array}$ & $\begin{array}{c}\text { Steel - } \\
\text { Polyethylene }\end{array}$ & $\begin{array}{c}\text { Steel- } \\
\text { Polyethylene }\end{array}$ \\
\hline Substrate & & Rockwool & Rockwool & & Rockwool & Rockwool & Soil \\
\hline Planting date & & Nov-Dec & Dec.Jan. & & Nov.-Dec. & Dec.Jan. & Mar.-Apr \\
\hline Hanest & & Feb-Oct & Feb.-Oct & & Feb-Oct & Feb - Oct & Jun-Sep \\
\hline \multirow[t]{2}{*}{ Heating } & & yes & yes & & yes & yes & no \\
\hline & Fuel & 135 & 12 & & 13.5 & 12 & \\
\hline \multirow[t]{2}{*}{ Heating energy used (\% surface) } & Gas & 86.5 & 86 & & 86.5 & 86 & \\
\hline & Wood & 0 & 2 & & 0 & 2 & \\
\hline CO2 enrictment & & yes & yes & & yes & yes & no \\
\hline Energy consumption ( $k$ Wh $m-2$ ) & & $365 \pm 116$ & $240 \pm 108$ & & $365 \pm 116$ & $216 \pm 108$ & \\
\hline Plant density (m-2) & & $1.2^{*}$ & $1.2^{2}$ & $12^{\circ}$ & $1.2^{\mathrm{a}}$ & $1.2^{\mathrm{a}}$ & 2 \\
\hline Vrigation and Fertilization & & Fertigation & Fertigation & & Fertigation & Fertigation & Soit \\
\hline \multirow[t]{3}{*}{ total water inputs (1.m-2) } & & 1250 & 1250 & & 1250 & 1250 & 500 \\
\hline & $N$ & 2561 & 2561 & & 2561 & 2561 & 450 \\
\hline & $\mathrm{P} 2 \mathrm{O} 5$ & 1401 & 1401 & & 1401 & 1401 & 300 \\
\hline \multirow[t]{3}{*}{ Nutrient inputs (Kg.ha-1) } & $\mathrm{k} 2 \mathrm{O}$ & 5378 & 5378 & & 5378 & 5378 & 900 \\
\hline & $\mathrm{CaO}$ & 2499 & 2499 & & 2499 & 2499 & 300 \\
\hline & $\mathrm{MgO}$ & 804 & 804 & & 804 & 804 & 90 \\
\hline Biological control & & yes & yes & & yes & yes & no \\
\hline Pesticides & & $\begin{array}{l}\text { Fungicides + } \\
\text { insecticides } \\
\text { (when } \\
\text { necessary) }\end{array}$ & $\begin{array}{l}\text { Fungicides + } \\
\text { insecbicides } \\
\text { (when } \\
\text { necessary) }\end{array}$ & & $\begin{array}{l}\text { Fungicides + } \\
\text { insecticides } \\
\text { (when } \\
\text { necessary) }\end{array}$ & $\begin{array}{l}\text { Fungicides + } \\
\text { insecticides } \\
\text { (when } \\
\text { necessary) }\end{array}$ & $\begin{array}{l}\text { Fungicides + } \\
\text { nsecticides }\end{array}$ \\
\hline \multirow[t]{2}{*}{ weed control } & & no & no & & no & no & Plastic mulch \\
\hline & Bulk & 50 & 40 & & 50 & 40 & 15 \\
\hline \multirow[t]{3}{*}{ Yields (Kg.m-2) } & On the vine & 50 & 36 & & 50 & 36 & \\
\hline & Special types & 25 & 25 & & & 25 & \\
\hline & Bulk & 1.17 & 1.17 & & 1.17 & 1.17 & 0.94 \\
\hline \multirow[t]{2}{*}{ Market prices (€.Kg-1) } & On the vine & 1.26 & 1.26 & & 1.26 & 1.26 & \\
\hline & Special types & 3.99 & 3.99 & & 3.99 & 3.99 & \\
\hline
\end{tabular}


Table 2. Considered application rates of a.i.'s for tomato production in respectively tunnel and heated greenhouse production.

\begin{tabular}{|c|c|c|c|c|c|}
\hline & Variable & $\begin{array}{c}\text { Application rate } \\
\left(\mathrm{kg} \text { a.s. }{ }^{*} \mathrm{ha}^{-1}\right)\end{array}$ & & Variable & $\begin{array}{l}\text { Application rate } \\
\left(\text { kg a.s. }{ }^{*} \text { ha }^{-1}\right)\end{array}$ \\
\hline$\underset{\Xi}{\stackrel{\Xi}{\Xi}}$ & $\begin{array}{c}\text { Abamectin } \\
\text { Pyriproxyfen } \\
\text { Acetamiprid } \\
\text { Pymetrozin } \\
\text { Myclobutanil } \\
\text { Methomyl } \\
\text { Propamocarbe } \\
\text { Diethofencarb } \\
\text { Carbendazim } \\
\text { Iprodion } \\
\text { Copper-sulfate }\end{array}$ & $\begin{array}{l}0.009 \\
0.013 \\
0.025 \\
0.100 \\
0.150 \\
0.290 \\
0.360 \\
0.500 \\
0.500 \\
1.000 \\
4.000\end{array}$ & 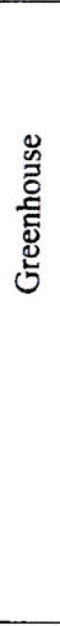 & $\begin{array}{l}\text { Hexythiazox } \\
\text { Abamectin } \\
\text { Pyriproxyfen } \\
\text { Hexaconazole } \\
\text { Indoxacarb } \\
\text { Glyphosat } \\
\text { Fenhexamid } \\
\text { Pymetrozin } \\
\text { Bupirimate } \\
\text { Fenbutatin-oxid } \\
\text { Cyromazine } \\
\text { Pyrimethanil } \\
\text { Diethofencarb } \\
\text { Iprodion } \\
\text { Carbendazim } \\
\text { Chlorthalonil } \\
\end{array}$ & $\begin{array}{l}0.003 \\
0.018 \\
0.025 \\
0.030 \\
0.038 \\
0.072 \\
0.750 \\
0.300 \\
0.500 \\
0.513 \\
0.600 \\
0.800 \\
1.000 \\
1.000 \\
1.000 \\
1.440 \\
\end{array}$ \\
\hline
\end{tabular}

Table 3. Impacts per category and per $\mathrm{kg}$ of tomatoes for the different tomato production systems studied in France for the years 2006-2008. S refers to south-east region (Mediterranean and lower Rhone valley) and $\mathrm{N}$ to north-west region (Brittany and Lower Loire valley). TTP: Terrestrial ecotoxicity; HTTP: Human ecotoxicity; ATP: Aquatic ecotoxicity. 1.4-DCB: 1.4-dichlorobenzene-equivalents. TEG water: water + triethylene glycol.

\begin{tabular}{|c|c|c|c|}
\hline Systems & $\begin{array}{c}\text { TTP } \\
(\mathrm{kg} \mathrm{1.4-DCB} \mathrm{eq)})\end{array}$ & $\begin{array}{c}\text { HTP } \\
(\mathrm{kg} 1.4-\mathrm{DCB} \text { eq })\end{array}$ & $\begin{array}{c}\text { ATP } \\
\text { (kg TEG water) }\end{array}$ \\
\hline Glass S. Vine & 0.0047 & 0.258 & 252 \\
\hline Glass S. Bulk & 0.0039 & 0.211 & 223 \\
\hline Glass N. Vine & 0.0040 & 0.263 & 209 \\
\hline Glass N. Bulk & 0.0037 & 0.247 & 206 \\
\hline Plastic S. Vine & 0.0045 & 0.290 & 158 \\
\hline Plastic S. Bulk & 0.0038 & 0.240 & 139 \\
\hline Plastic N. Vine & 0.0048 & 0.356 & 174 \\
\hline Plastic N. Bulk & 0.0045 & 0.336 & 171 \\
\hline Multi span & 0.0042 & 0.275 & 192 \\
\hline Tunnel & 0.0009 & 0.122 & 12.7 \\
\hline
\end{tabular}




\section{Figures}
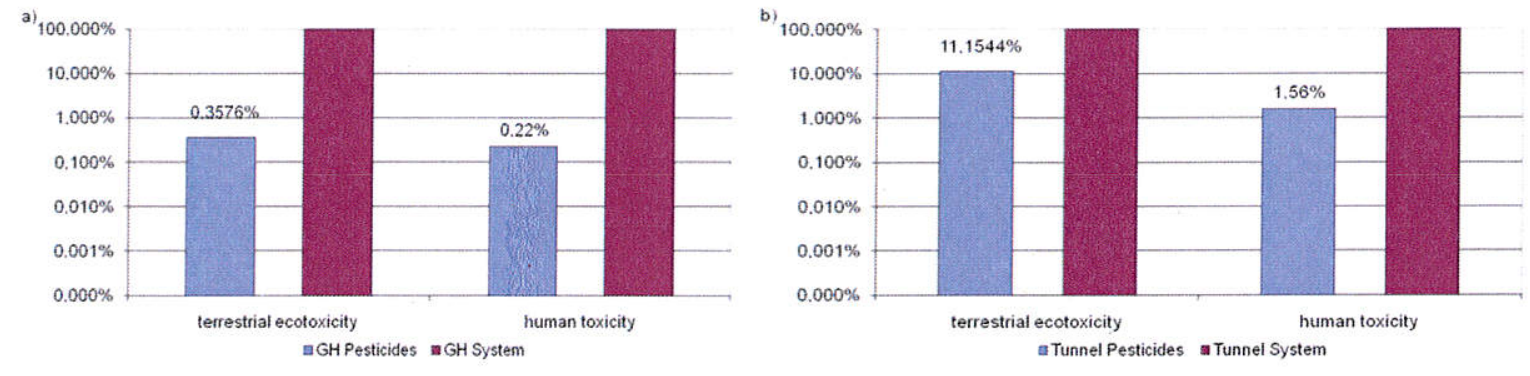

Figure 1: Relative impacts of pesticides (scenario 1 and including copper sulphate) emitted from multi-span greenhouses (a) and tunnels (b) compared to the whole system (without pesticide application but including pesticide manufacture). Note the logarithmic progression of the ordinate scale and the omission of aquatic ecotoxicity because the use of different methods for pesticides and system impact assessments.

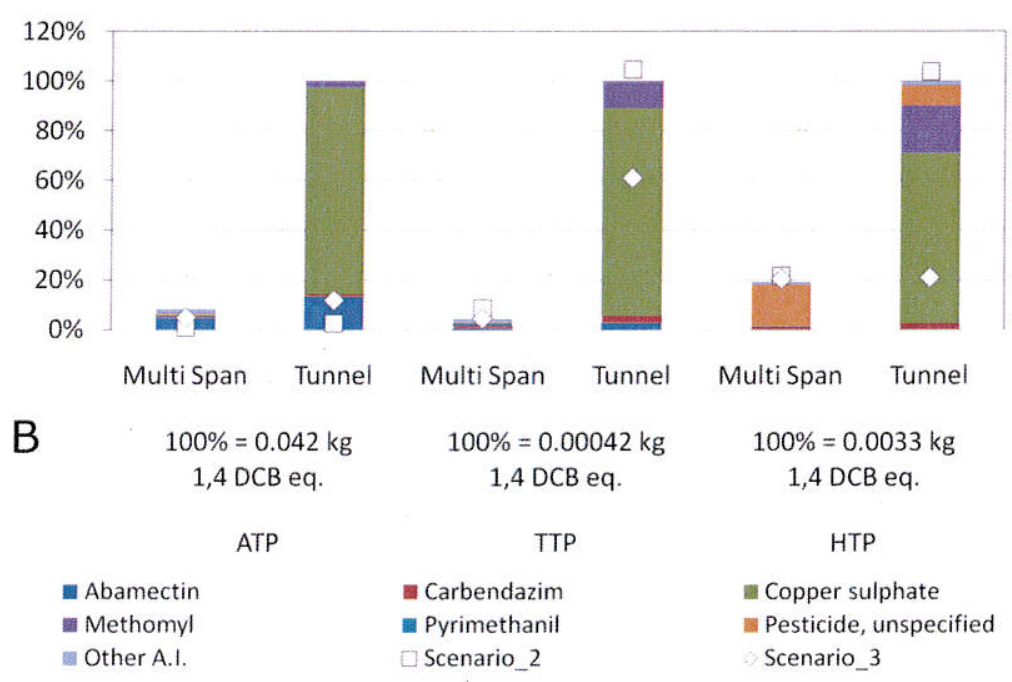

Figure 2. Aquatic ecotoxicity, terrestrial ecotoxicity and human toxicity per $\mathrm{kg}$ of tomatoes according to USES-LCA. Impacts are presented relative to the tunnel system for each impact category. All pesticides which could not be characterized are summarized as pesticide unspecified. TTP = Terrestrial ecotoxicity; HTTP = Human ecotoxicity; ATP = Aquatic ecotoxicity . 


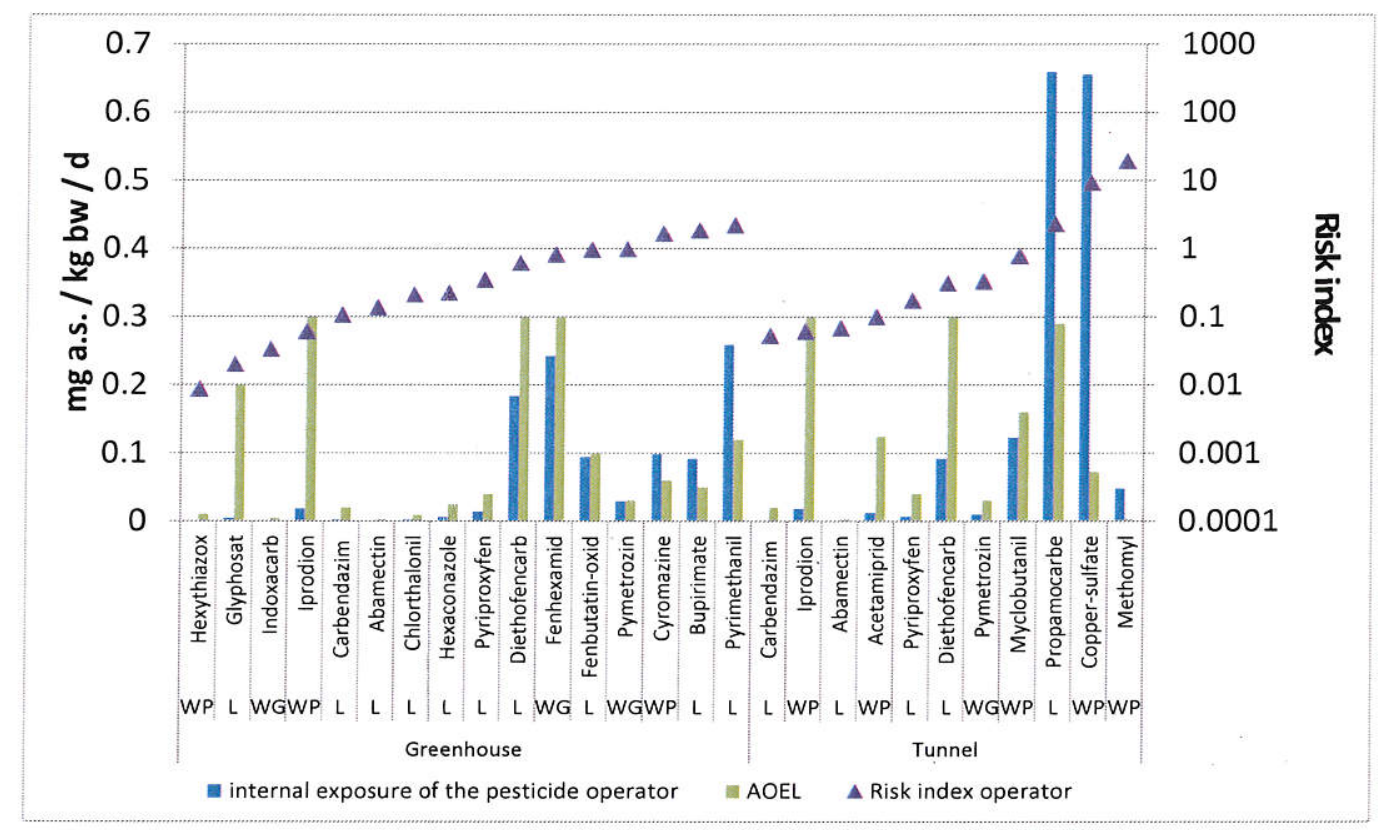

Figure 3 :Internal exposure, AOEL and risk index of operators for the different a.i.'s used in multispan's greenhouses and tunnels for tomato production.

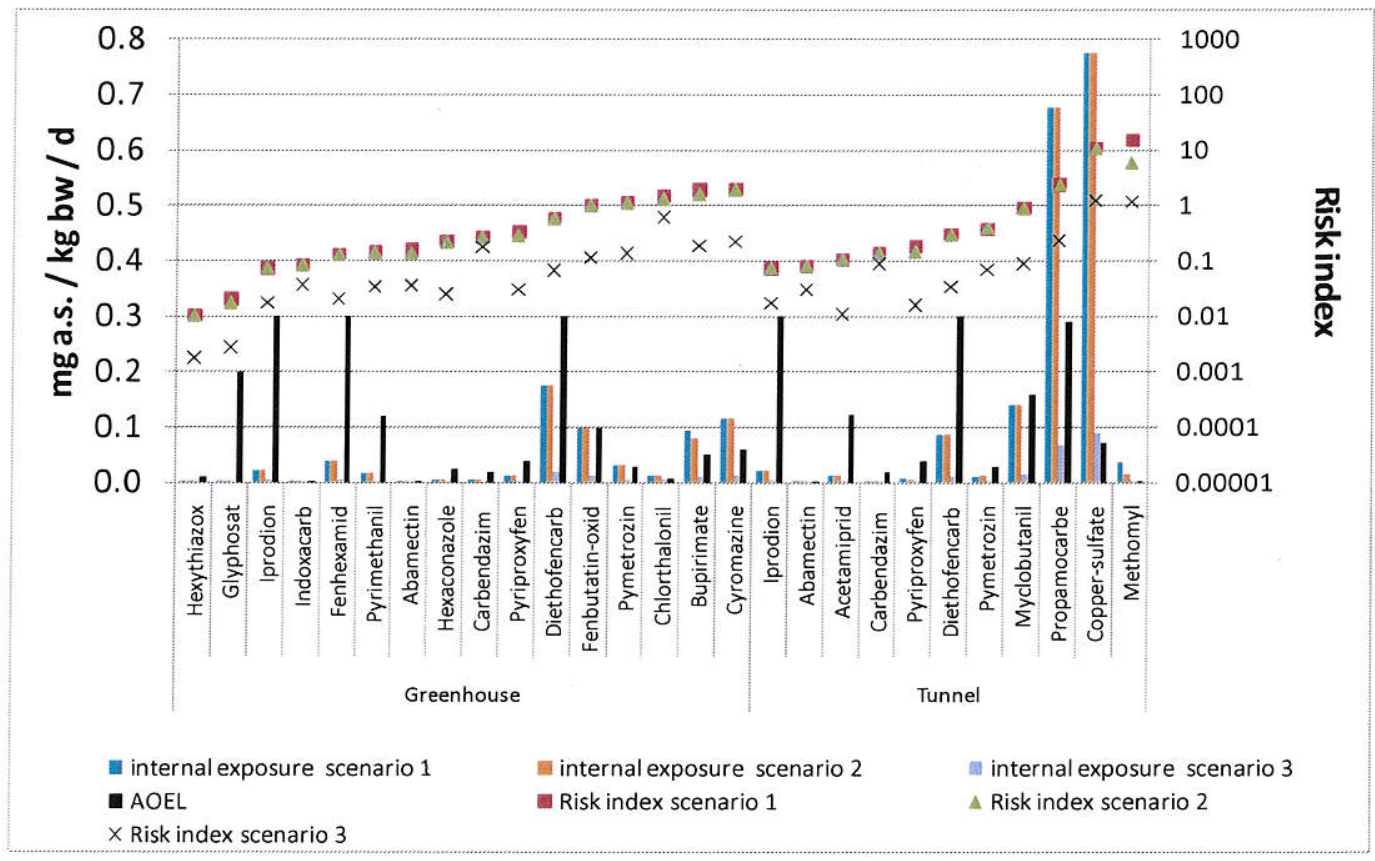

Figure 4 :Internal exposure, AOEL and risk index of re-entry workers according to the 3 considered scenarios for the different a.i.'s used in multispan's greenhouses and tunnels for tomato production. 